\title{
Rearing of Germfree Chicks in a Vinyl Isolator
}

\author{
Teru Ishibashi, Masao Kametaka, Akira Ozaki*, Testuzo Yamamoto*, \\ Choji Kaneuchi* and Tomotari MitsuoKa* \\ Department of Agricultural Chemistry, Faculty of Agriculture, \\ The University of Tokyo, Tokyo 113 \\ * Laboratory of Animal Physiology, Institute of Physical and \\ Chemical Research, Wako-shi 351
}

(Received April 8; 1977)

\begin{abstract}
A method of rearing germfree chicks in a vinyl isolator was developed, Hatchability of eggs was higher than $95 \%$ when eggs were sterilized in a $1.5 \%$ mercuric chloride solution on the 2 nd day before hatching. Sterility was $93 \%$ when 5 to 10 chicks were reared in a vinyl isolator for 2 weeks. Depression of body weight gain was observed in chicks fed diet irradiated at higher than $4 \mathrm{Mrad}$. However, no effects of irradiation on chick growth were observed when fat and the other components were sterilized separately and mixed before feeding. The growth rates of germfree chicks were higher than those of the conventional chicks which were supplied a diluted solution of fresh cecum feces of young hens with a normal intestinal flora pattern at the first feeding.
\end{abstract}

From the pioneer experiments, it is concluded that life without bacteria is impossible due to the lack of sufficient knowledge of the principles of nutrition which we have today. The turning point came in 1912 when COHENDY ${ }^{12}$ found that he could raise germfree chicks satisfactorily. In 1937, BALzaM ${ }^{2)}$ found that germfree chicks could grow at about the same rate as conventional chicks fed the same sterilized diet. In 1949, Reyniers et al. ${ }^{3)}$ succeeded in egg production from germfree hens and hatching their eggs. However, studies on the nutrition of germfree chickens have not been pursued vigorously, because of difficulties in reproduction in germfree conditions due to the larger body size and longer life cycle of chickens in contrast to small rodents.

In Japan, KaNEUCH and his coworkers ${ }^{4,5)}$ devised an inexpensive germfree chicken cage that could be used for feeding experiments over 3 or 4 weeks. Their method is of small scale and advantage of reducing the loss of animals by microbial contamination to the minimum extent. Consequently it has conveniently been used in such experiments as to test establishment of various kind of microorganisms in the germfree chicks. The cage, however, has the following disadvantages: the number of chicks which can be reared simultaneously is limited and the cage is not large enough to prepare a purified diet in it. As will be described later, fat and other components of the purified diet should be mixed after sterilized separately.

Since that time, vinyl isolators have been employed successfully in research on germfree animals. The present report describes our hatching tank and vinyl isolator which have been improved to rear to many chicks simultaneously based on the techniques developed by KanEuchi et al.., 51

Jap. J. Zootech. Sci., 48, (9): 489-497. 


\section{Materials and Methods}

Procedure for preparing germfree chicks. Broiler chicks of the Cobb strain were used in all experiments; the male chicks were white and the females brown. Eggs from 1 to 3 days before hatching were purchased from a commercial hatchery. They were immersed in a $1.5 \%$ mercuric chloride solution at 37 to $39^{\circ} \mathrm{C}$ and gently rotated to achieve immersion of all sides in this germicidal solution for 5 to 7 minutes. Twenty to 30 eggs were transferred to the hatching cage in a tank shown in Fig. 1. Prior to each experiment, this tank was tested for leaks by filling with

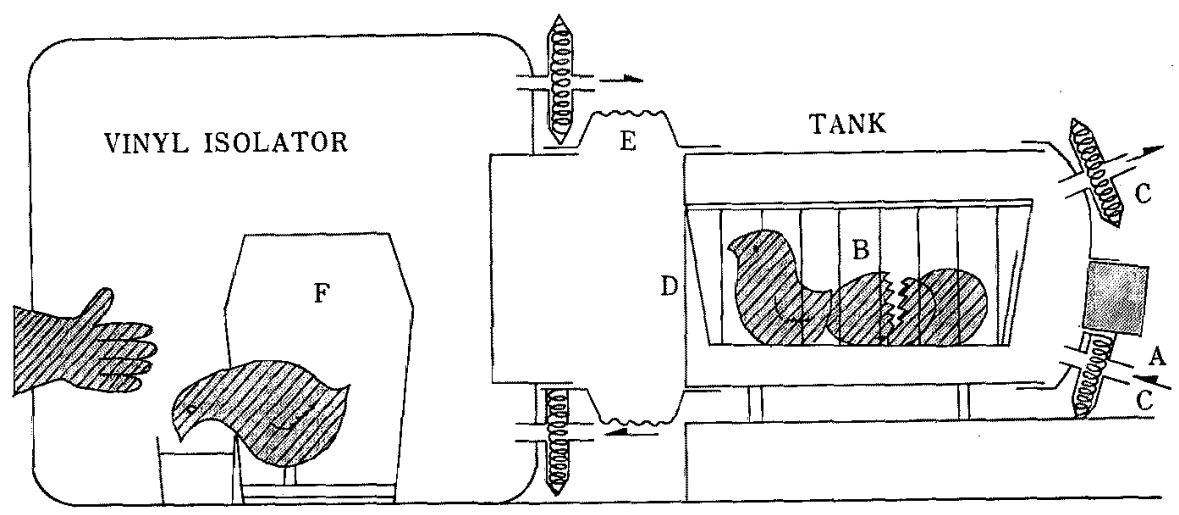

Fig. 1. Apparatus and procedure to rear germfree chicks. Eggs on the 2nd day before hatching are immersed in a $1.5 \%$ mercuric chloride solution at 37 to $39^{\circ} \mathrm{C}$ for 5 to 7 minutes. Then 20 to 30 eggs are transferred to a cage made of polyvinyl chloride (B) in a tank (30 cm in diameter and $45 \mathrm{~cm}$ in length) through an inlet of eggs (A). The tank is placed in a small hatchery box. After hatching, the other side of air filters (C) which is sealed with a Mylar film (D) is docked with a vinyl isolator $(90 \mathrm{~cm}$ in width, $90 \mathrm{~cm}$ in height and $150 \mathrm{~cm}$ in length) via a vinyl sleeve (E). Some chicks needed for experiments are transferred to an individual cage (F) in the vinyl isolator.

air and sterilized with about $100 \mathrm{~m} l$ of a $2 \%$ peracetic acid solution. The tank was sealed and allowed to stand for 1 hour before ventilating. The air filter was presterilized at $125^{\circ} \mathrm{C}$ for 1 hour before being attached to the tank. The filter was also subsequently exposed to peracetic acid vapor during sterilization of the tank.

The tank with eggs was placed in a small commercial hatchery box. Five to 10 chicks needed for experiments were transferred into a cage in a vinyl isolator within 24 to 48 hours after hatching. Each vinyl isolator was tested for leaks and sterilized before ventilating by a centrifugal blower fan.

Fresh excreta were collected for microbial contamination test on the 7 th and 14th days after feeding. The bacteriological procedures were essentially the same as those described by the Committee for Standardization of Sterility Tests for Germfree Animals in Japan') in 1972.

All chicks were fed the experimental diets within 24 and 48 hours after hatching. The chicks which were not transferred into an isolator were used as a conventional group. They were supplied a diluted solution of fresh cecum feces of young hens with a normal intestinal fora pattern as shown in Table 1. 
Table 1. Cecum faecal flora of maternal hen

\begin{tabular}{lc}
\hline & $\left(\log _{10}\right)$ \\
Total & 11.0 \\
Bacteroidaceae & 10.7 \\
Eubacteria & 10.3 \\
Peptostreptococci & 10.2 \\
Clostridia & 9.6 \\
Curved rods & 8.6 \\
Bifidobacteria & 8.1 \\
Lactobacilli & 7.8 \\
Streptococci & 7.2 \\
Enterobacteria & 5.7 \\
Bacillus & 5.3 \\
Staphylococci & 4.2 \\
\hline
\end{tabular}

Sterilization of diet and drinking water. Two kinds of diets were used in this experiment. One was a commercial diet containing $24.7 \%$ crude protein, $6.2 \%$ crude fat and $3090 \mathrm{kcal} / \mathrm{kg}$ of metabolizable energy. The other was an amino acid diet containing $20.0 \%$ amino acid mixture ${ }^{7}, 10 \%$ fat and $3960 \mathrm{kcal} / \mathrm{kg}$ of metabolizable energy. The diets were packed in two folded heat-sealed polyethylene bags before radiation exposure to a ${ }^{60} \mathrm{Co}$ source with a capacity of $12 \mathrm{~K}$ Curies at the Institute of Physical and Chemical Research in Wako-city, Saitama Prefecture.

Tap water was autoclaved at $1200^{\circ} \mathrm{C}$ for 1 hour with other materials which were not suitable for sterilization by peracetic acid in a sterilized tank. Diets, tap water and other materials indispensable for feeding of chicks were incorporated into the isolator before transferring the chicks.

Effects of sterilization of eggs, water and diets on chick growth. To investigate the effects of sterilization of eggs by mercuric chloride on growth of chicks, one-day-old male chicks which hatched from sterilized or nonsterilized eggs received the commercial diet for 12 day. To examine the effects of sterilization of tap water on chick growth, one-day-old conventional male chicks received the commercial diet and sterilized or nonsterilized water ad libitum for 7 days.

To investigate the effects of $\gamma$-ray irradiation of diets, 4-day-old conventional male chicks were given ad libitum the irradiated 1) commercial diet, 2) amino acid diet or 3) amino acid diet in which fat and other components were separately sterilized and mixed before feeding for 10 days.

The irradiated doses were $0.0,1.0,2.0,4.7,8.1$ and $12.0 \mathrm{Mrad}$ for the commercial diet, 0.0 , 5.2 and $12.0 \mathrm{Mrad}$ for the amino acid diet and 5.0 and $12.0 \mathrm{Mrad}$ for the amino acid diet sterilized separately.

Comparative growth rates of germfree and conventional chicks. Growth rates of 4-day-old germfree and conventional chicks fed the $4.7 \mathrm{Mrad}$ irradiated commercial diet were compared with those of commercial chicks fed the nonirradiated diet for 11 days. After the feeding test, the chicks were sacrificed and weights of the liver, pancreas, duodenum, jejunum and cecum were measured.

\section{Results}

Germfree chicks remained healthy in appearance and no evidence of disorders was observed throughout the experiments. The comparison of the present hatchability and sterility with other 


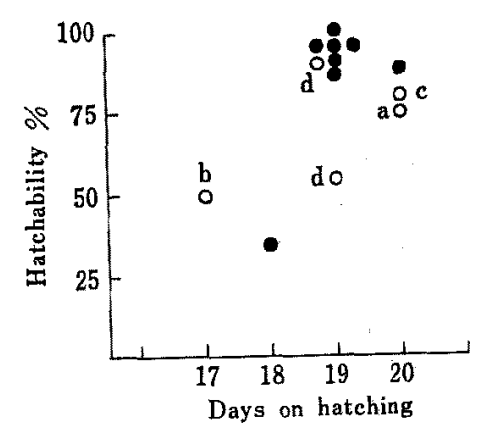

Fig. 2. Hatchability of eggs sterilized on 1 to 3 days before hatching. Cited data are;

a, Kaneuchi et al. b, Phillips et al.

c, ReYNiers et al. d, Harrison.

Table 2. Sterility of chicks fed for 14 days with 5 to 10 chicks in an isolator after hatching in a tank with 20 to 30 eggs

\begin{tabular}{ccccc}
\hline Workers & Eggs $^{+}$ & Chicks $^{++}$ & $\begin{array}{c}\text { Feeding period } \\
\text { (Days) }\end{array}$ & $\begin{array}{c}\text { Sterility } \\
(\%)\end{array}$ \\
\hline KANEuchi et al. & 2 & 2 & 2 & 90 \\
& 2 & 1 & 25 & 70 \\
PhILLIPS et $a l$. & $10-20$ & - & 1 & 97 \\
ReYNIERS et al. & $1-3$ & - & 1 & 100 \\
& $15-18$ & - & 1 & 88 \\
HARRISON & $(7)$ & $(3-6)$ & 28 & 83 \\
\hline Present report & $20-30$ & $5-10$ & 14 & 93
\end{tabular}

+ Number of eggs placed in a hatchery apparatus.

${ }^{++}$Number of chicks reared in an isolator.

results ${ }^{3,5,7,8)}$ are shown in Fig. 2 and Table 2. The hatchability of eggs sterilized 3,2 and 1 day before hatching were 43,95 and $88 \%$, respectively. One-third of the eggs 1 day before hatching began to peep in a hot mercuric solution. Therefore, in the later experiments, the eggs were sterilized 2 days before hatching.

Sterility of chicks decreased with the number of eggs placed in the same hatching cage as shown by the data of REYNIERS $e t a l{ }^{3}{ }^{3}$ and with the number of days after feeding in the data of KANEUCH et al. ${ }^{5)}$ In our experiments, 13 out of 14 isolators in which 5 to 10 chicks were reared for 2 weeks were kept in a germfree condition from a bacteriological standpoint. In one isolator; contamination was frst noticed on the 7 th day. The sources of this contamination were not determined.

Figure 3 shows no significant effects on chicks growth of sterilization of water by autoclaving and of eggs by the mercuric solution.

Effects of irradiation of the diets are summarized in Fig. 4. When the irradiated commercial 


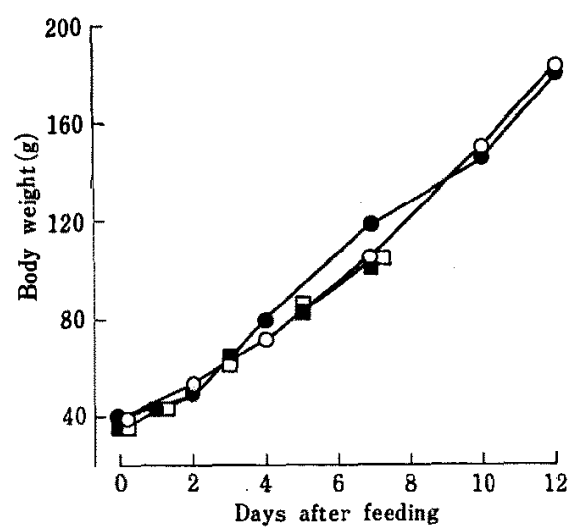

Fig. 3. Effects of sterilization of tap water by autoclaving and eggs by a mercuric chloride solution on the chick growth. Symbols are; $\bullet$, Sterilized eggs, 0 , Nonsterilized eggs, $\mathbf{m}$, Sterilized tap water; $\square$, Nonsterilized tap water.

diets were supplied, daily gain of body weight decreased when the dose exceeded $2.0 \mathrm{Mrad}$. Low body weight gain of chicks fed highly irradiated diets resulted from a lower feed conversion ratio rather than less feed intake. When the whole amino acid diets were irradiated, the daily gain of body weight and feed intake decreased significantly. On the other hand, when fat and the other components of the amino acid diet were sterilized separately followed by mixing, no adverse effect on daily weight gain and feed intake was observed even when the components except fat of the former diet was irradiated at $12 \mathrm{Mrad}$.

Body weight gain, feed intake and feed conversion ratio of germfree and conventional chicks fed irradiated or nonirradiated commercial diets for 11 days are summarized in Table 3 . In comparison with conventional groups, the body weight gain and feed intake of the irradiated group were significantly less than those of the nonirradiation group, but the feed conversion ratio was not significantly different. In a comparison of the conventional and germfree groups, significantly superior weight gain and feed conversion ratio were obtained in the germfree group.

The tissue weights per $100 \mathrm{~g}$ of body weight of the germfree and conventional chicks on the

Table 3. Body weight gain, feed intake and feed conversion ratio of germfree and conventional chicks

\begin{tabular}{llccc}
\hline \multicolumn{1}{c}{ Chick } & \multicolumn{1}{c}{ Diet } & $\begin{array}{c}\text { Body weight gain } \\
\text { g/chick/day }\end{array}$ & $\begin{array}{c}\text { Feed intake } \\
\text { g/chick/day }\end{array}$ & $\begin{array}{c}\text { Feed conver- } \\
\text { sion ratio }\end{array}$ \\
\hline Conventional & Nonirradiated & $19.3^{\mathrm{a}}$ & $26.2^{\mathrm{a}}$ & $1.36^{\mathrm{a}}$ \\
Conventional & Irradiated & $17.5^{\mathrm{b}}$ & $24.3^{\mathrm{b}}$ & $1.39^{\mathrm{a}}$ \\
Germfree & Irradiated & $19.6^{\mathrm{a}}$ & $24.5^{\mathrm{b}}$ & $1.25^{\mathrm{b}}$ \\
\hline
\end{tabular}

The values are means of 8 male chicks fed irradiated (4.7 Mrad) or nonirradiated commercial diet for 11 days from 3 to 14 days after feeding. Means bearing the different superscripts differ significantly $(\mathrm{P}<0.05)$. 

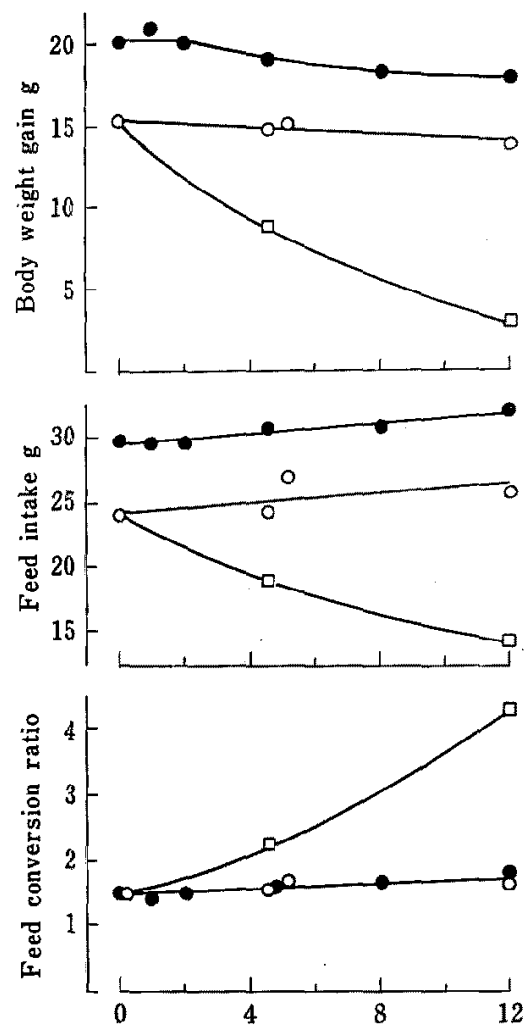

Fig. 4. Effects of lrradiation to commercial ( ) and purified diets with ( $\square$ ) or without (O) fat on weight gain, feed intake and feed conversion ratio. Each point is the mean of 3 male chicks fed for 9 days from 3 to 12 days after feedig.

irradiated diets are shown in Fig. 5 as percentage of conventional chicks fed the nonirradiated diets. In the conventional-irradiated group, the weights of the liver and pancreas were signif. icantly higher, but those of the upper half of the duodenum and jejunum were not significantly higher than those of the conventional-irradiated group. All weights of tissues tested in the germfree group were significantly lower than those of the conventional-irradiated group.

\section{Discussion}

One of the main purposes of these experiments was to develop a method of rearing germfree chicks in a vinyl isolator. As shown in Fig. 1 and Table 2, satisfactory results with few defects and a high hatchability and sterility were obtained by the method used.

In contrast to the results in rodents ${ }^{10,11)}$, the daily gain of body weight decreased with increasing dose levels on the whole in the case of the chicks given the irradiated diets. Marked depression of body weight gain and feed intake was observed with the amino acid diets. No adverse effect was found in the chicks fed the amino acid diet in which fat and the other components 


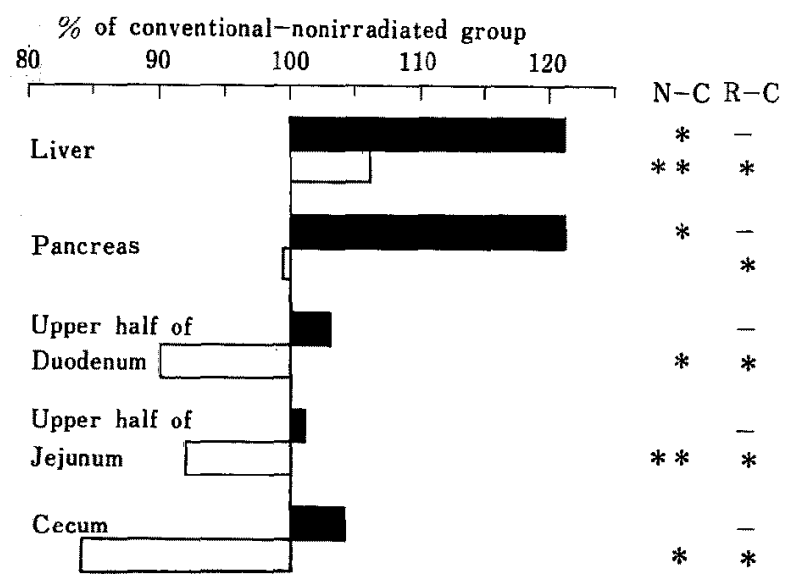

Fig. 5. Comparison of tissue weights per $100 \mathrm{~g}$ body weight of conventional ( $\mathbf{\square})$ and germfree chicks ( $\square$ ) on $4.7 \mathrm{Mrad}$ irradiated diets with those of conventional chicks on nonirradiated diet $(100 \%)$. N-C; Significantly different from the conventional-nonirradiated group. $\mathrm{R}-\mathrm{C}$, Significantly different from the conventionalirradiated group. *, $\mathrm{P}<0.01 ; * *, \mathrm{P}<0.05$.

were sterilized separately as observed by TAKIGAWA et al. ${ }^{12}$ They reported that when oil was not irradiated, no effect of irradiation of the other components on chick growth was observed. From the results mentioned above, it is concluded that the depression of daily gain of body weight is due to oxidation by irradiation ${ }^{11}$. The difference in the depression level of body weight gain at the high dose of irradiation between commercial and amino acid diets may be due mainly to the content of fat (6.2: 10.0\%), and partly to the form of fat in the diets.

IWado et al. ${ }^{10)}$ reported that sufflcient sterilization was achieved by exposure of the diets to $3 \mathrm{Mrad}$. In the present experiments, the authours decided to sterilize the diets at $4.7 \mathrm{Mrad}$ because accidential contaminations occurred by sterilization at $3 \mathrm{Mrad}$ in the primary experiment in the Institute of Physical and Chemical Research.

As shown in Table 3, the germfree chicks gained more weight than the conventional controls as reported by CoATEs et al, ${ }^{13)}$ The weights of the liver and pancreas in germfree chicks were higher than those of conventional chicks on the irradiated diet as expected from the data of TAKIGAWA et al. ${ }^{12)}$ The tissue weights of intestine and cecum, especially the latter in contrast to the rodents ${ }^{10)}$, were significantly lower than those of the conventional chicks.

These results suggest that the function of bacterial association can have an important effect on the metabolism of the host.

The work of LEPKOVSKY et al. ${ }^{14)}$ showed that the amylase activity in the digestive tract of the chicken was greatly elevated in the ceca and cloaca in the absence of intestinal microflora; pancreatic amylase was usually destroyed by bacterial protease in the conventional bird. However, it is not clear to what extent this elevated enzyme activity infuences the digestion of starch, the most plentiful dietary component, and energy metabolism.

Notwithstanding the fact that somewhat better utilization of fat was shown in the germfree 


\section{Ishibashi, Kametaka, Ozaki, Yamamoto, Kanguchi and Mitsuoka}

rat, largely because digestive utilization of palmitic and stearic acid increased by approximately 10 and 15 percentage points respectively ${ }^{15)}$, no large difference has been found in uptake of fatty acids from the diets' ${ }^{16)}$. Further studies will be required to establish whether or not this phenomenon influences the rapid growth rate of germfree chicks.

YAMANAKA et al. ${ }^{17}$ have reported a slightly higher nitrogen retention in young germfree mice. In addition, a somewhat faster absorption of certain amino acids seems to take place in the $a b$. sence of intestinal fora ${ }^{187}$, but since dietary protein is usually utilized by $95 \%$ or more any way, it is doubtful whether this latter observation indicates a possible effect on protein requirements. The effect of intestinal flora on metabolism of nitrogen compounds will be clarified in the following series of studies.

\section{References}

1) Cohendy, M., Ann Inst Pasteur 26: 106-137. 1912.

2) Balzam, N., Acta Biol Exptl 11: 43-56. 1937.

3) Reyners, J.A., P.C. Trexler, R. F. Ervin, M. Wagner, T. D. Luckey, and H. H. Gorden, Lobund Rept No. 2: 1-116. 1949.

4) Kaneuchi, C., T. Mitsuoka, and S. Yamamoto, Jap J Zootech Sci 28: 1-9. 1966.

5) Kaneuchi, C., T Mitsuoka, S. Yamamoto, and T. Sega, Jap J Zootech Sci 28: 229-236. 1966.

6) The Committee for Standardization of Sterility Test for Germfree Animals in Japan, Expt Anim 21: 35-38. 1972.

7) Ishibashi, T., Jap J Zootech Sci 44: 39-49. 1973.

8) Phillips, A. W., H.R. Newcomb, R. Lachapelle, and E. Balish, Appl Microbiol 10: 224-230. 1962.

9) Harrison, G. F., Lab Anim 3: 51-59. 1969.

10) Iwado, S., Y. Suzuki, H. Iizuka, S. Shibage, and K. Nakagawa, Exp Anim 19: 77.81. 1970.

11) Ford, D. J., Brit J Nutr 35; 267-276. 1976.

12) Takigawa, A., H. Danbara, and Y. Ohyama, Jap J Zootech Sci 47: 292-302. 1976.

13) Coates, M. E., R. Fuller, G.F. Harrison, M. Lev, and S. F. Suffalk, Brit I Nutr 17: 141150. 1963.

14) Lepkovsky, S., M. Wagner, F. Furuta, K. Ozone, and T. Korke, Poultry Sci 43: 722-726. 1964.

15) Demarne, Y., J. Flanzy, and E. Sacquet, Germfree Research 553-560. Academic Press. New York. 1973.

16) Witch, H. L., J.G. Hamilton, and O. N. Miller, J Nutr 93: 324-330. 1967.

17) Yamanaka, M., T. Nomura, and M. Kametaka, J Nutr Sci Vitaminol 20: 389-400. 1974.

18) Herskovic, T., J. Katz, M.H. Floch, R. D. Spencer, and H. M. Spiro, Gastroenterology (Abstr) 52: 1136. 1967. 


\title{
ビニルアイソレーター中での無菌ヒナの飼育法
}

\author{
石橋 晃・亀高正夫・尾崎 明* .山本哲三* \\ 金内壆司 $*$ 光岡知足 $*$
}

東京大学農学部, 東京都 113

* 理化学研究所動物薬理研究室, 和光市 351

ヒナを同時に多数羽ふ化し，無菌的に飼育できる方法

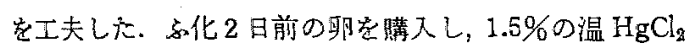
液中に5-7分つけて隇菌し，あらかじ $2 \%$ 過酶酸液を 滅菌したふ卵タンタに20-30 畉入れて通気させながらら 化した．5化率は 95\%であった．与化後試験に必要な 羽数 5-10 羽を無苜ビニルアイソレレーターに移し，ただ ちに䭒付けして 2 週間飼育しで。7，14 日目に無菌テス
トをした結果，無菌率は 93\%(14 フイソレーター中 13 例)であった，飼料はケ線で隇菌した，精製飼料全体に

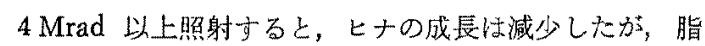
肪を別にして照射し，給与前に混合すると成長に及ぼす 影響は少なかった。無菌とナは通常ヒナよりも成長が早

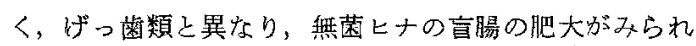
なかった。 